\title{
A Research on the Belt and Road Initiatives and Strategies of RMB Internationalization
}

\author{
Xuejun Lin ${ }^{1}$, Yefen Xiao ${ }^{1}$, Yuan Liang ${ }^{1} \&$ Xiaowen Zhang ${ }^{2}$ \\ ${ }^{1}$ International Business School, Jinan University, Qianshan, Zhuhai Guangdong, China \\ ${ }^{2}$ School of Translation Studies, Jinan University, Qianshan, Zhuhai Guangdong, China \\ Correspondence: Yuan Liang, International Business School, Jinan University, Qianshan, Zhuhai Guangdong, China. \\ Tel: 86-137-7828-6236.
}

Received: December 31, 2016

Accepted: January 17, $2017 \quad$ Online Published: January 23, 2017

doi:10.5430/bmr.v6n1p13

URL: http://dx.doi.org/10.5430/bmr.v6n1p13

\begin{abstract}
Some problems exist in current international monetary system, such as dollar dominance and frequent fluctuation of exchange rate, which are not conducive to the development of trade, investment and global economy. Financial crises break out frequently. So we should reform the international monetary system and create a multi-polar international monetary system to regulate dollar conduct by mutual competitions. RMB internationalization is not only favorable to the stability of the world's currency, but also good to China's own development. The Belt and Road Initiative has been bringing more opportunities for the internationalization of the RMB. The Belt and Road Initiative aims to strengthen economic cooperation between China and its neighboring countries and promotes the regional economic prosperity. This strategy provides a good opportunity for China to develop trade, increase investment and expand financial markets. So RMB should take advantage of this opportunity to improve the proportion of RMB trade settlement, increase the amount of RMB investment and financing and accelerate the circulation of RMB, and then steadily push forward the process of RMB internationalization under the premise of controlling risks.
\end{abstract}

Keywords: RMB internationalization, The Belt and Road, Opportunity, Risk

\section{Introduction}

Events like Southeast Asian financial crisis happening in 1998 and United States "Financial Tsunami" happening in 2008 had a great impact on global economy, impelling us to seriously consider the current international monetary system. In Jamaican System, every country executes the floating exchange rate. The dollar is the main international currency. Many experts and scholars believed that is an international monetary system without institution or constraint, which is the main cause of the frequent occurrence of international financial crisis.

The reasons are as follows. Firstly, in the existing system, the responsibilities of the dollar don't equal to the rights of it. America monopolizes seignorage, only caring about domestic policies, ignoring the international repercussions. Too much issuance of the dollar causes dollar glut and great exchange rate fluctuation, which result in the frequent occurrences of crises. The second reason is that America's adverse balance continues to widen. Triffin Dilemma of dollar is difficult to solve. Lastly, America continuously enlarges its scale of national debt to stimulate its economic growth. It even reached the extent of deficit spending. The credit of the dollar has been overdrawn. Thus, it's urgent to reform the international monetary system, to make it a system that stabilizes the value and exchange rate of currency and balance the rights and responsibilities. The system should be conducive to international trade and investment as well as the development of global economy.

Some feasible strategies to reform current international monetary system are as follows. Firstly, expand the use of SDR to make it the real international currency, not only used for the settlement of the government, reserves, debt, etc., but also used for general trade settlement an international investment. Secondly, internationalize the RMB and form a multi-polar international monetary system dominated by the dollar, euro and RMB. Currencies compete with each other and restrict each other.

In the process of reforming the international monetary system, China, as the world's second-biggest economy, should shoulder corresponding responsibility. Firstly, discuss with some international organizations like IMF and G20 about the reformation of international monetary system, reaching an international consensus. Secondly, take advantage of the opportunity of joining the SDR basket to strive to push ahead the process of RMB internationalization which 
benefits both the domestic economy and the international economy. The ways of RMB internationalize are as follows. The first thing is to expand the trade settlement in RMB. Second, expand the international investment in RMB. Thirdly, increase RMB as an international reserve currency. Put forward in 2013, "The Belt and Road" brought good opportunities of trade, investment and financing for the RMB internationalization. Thus, how to take advantage of this opportunity to promote the internationalization of the RMB is the focus of this paper. To summarize, the main purpose of this paper is to reform the current international monetary system, promote the internationalization of the $\mathrm{RMB}$, and push ahead the development of regional and global trade and investment.

This paper first reviews some viewpoints of experts and scholars on definition, conditions and ways of currency internationalization and its influence on domestic and foreign economy. Next, according to the current situation of RMB in international trade settlement, international investment and international reserves, the paper analyses the development process of RMB internationalization based on the index quantification of it. Thirdly, the paper looks back the various measures taken by the Chinese government and financial sectors in the process of RMB internationalization and points out the main problems existing in the process. Then, combining with the current construction of "The Belt and Road", it makes a comprehensive analysis of the opportunities and challenges "The Belt and Road" may bring to RMB internationalization. Lastly, considering the background of "The Belt and Road", it puts forward strategies for acceleration of the process of RMB internationalization.

\section{Literature Review}

\subsection{Definition of Currency Internationalization}

Yang Xiaohong (2003), Dong Shoukun and Yao Xiaoyi (1997) defined RMB internationalization as a process of RMB going out of the country, and becoming an instrument the whole world generally use for pricing, settlement, reserves and interference. The definition was based on the essence of currency internationalization,

From the perspective of the functions of the international currency, Hartmann (1998), Tavlas (1991) and others thought currency internationalization meant that the currency is accepted by the residents of a country besides the residents of the currency issuer, and is willingly used for exchange, account units and storage.

Scholars like Zhou Lin and Wen Xiaozheng (2001) interpreted the process of currency internationalization by using Stage Theory. They thought currency internationalization was a transitional process of current account and capital account of the currency opening from a low level to a high level. They divided the process into three stages, primary form of exchange relations with other countries' currency, intermediate forms of current project or capital project opening properly, advanced form of becoming other countries' hoard of foreign assets.

From the foregoing, we can find that most of the existing definitions of currency internationalization are mainly from the essence and functions of currency. Some scholars believe that the internationalization of currency is realized by stages, and it is a process that currency develop from the low level to the advanced level. This paper argues that RMB internationalization refers to the process that RMB can circulate abroad and become an internationally recognized currency for pricing, settlement and reserve.

\subsection{Conditions of Currency Internationalization}

Bergsten (1975) thought a currency to become an international currency should meet two conditions. One is that, in politics, the issuing country should own a strong political status and the support of international cooperation. The other is that the issuing country is a strong economy with a reasonable economic structure, which can maintain steady growth. The issuing country also has to maintain the balance of international payments and the reasonable balance of payments structure (Chou Kun, 2014).

Yang Huai (1999) thought that changes in the RMB exchange rate, domestic inflation rate and interest rates at home and abroad are important factors affecting RMB internationalization (Dong Shoukun, \& Yao Xiaoyi, 1997).

Yue Yiding and Zhangqi (2004) thought macroeconomic policy and the difference of national income level are the keys to the RMB internationalization (GS Tavlas, 1991).

Li Xiao, Li Junjiu and Ding Yibing held the perception that currency regionalization is a necessary step of currency internationalization (Gao Cailin, 2008). Thus, in the initial stage of RMB internationalization, it's more realistic and more important to realize RMB regionalization. Foreign scholars Yung Chul Park and Chi-Young Song (2011) also thought that researches on RMB internationalization mainly emphasize its regionalization, especially the Asia-Pacific region (Gao Haihong \& Yu yongding, 2010).

Cohen (2006) pointed out that there are three crucial factors of currency internationalization: the place currency has in finance markets, trade and central bank reserves (He Fan, 2009). 
Jeffrey Frankel (2012) thought economies of scale, confidence in currency and financial market depth are the basic elements of currency internationalization (Jeffrey A. Frankel, 1991).

Krugman (1980) thought the transaction cost of currency conversion is the factor that affects the currency internationalization. He pointed out that there is a scale effect of currency exchange, and the average transaction cost will decrease with the increase of the volume of transactions (Jeffrey A. Frankel, 2012).

From the foregoing viewpoints, in terms of the conditions of currency internationalization, the research of domestic and foreign scholars has been relatively adequate. Some scholars consider from macroscopic view, that currency internationalization cannot be separated from the political, economic, cultural and other conditions while other scholars, from microcosmic angles classify the lower transaction costs as the conditions of currency internationalization. This paper argues that the main condition of RMB internationalization is the strong economic strength, highly developed and open financial market and the stability of the currency.

\subsection{Path of RMB Internationalization}

The internationalization of a country's currency is a gradual process (Jiao Jijun, 2015) (see Table 1). From the perspective of the domain of influence, it includes surrounding usage, regionalization and globalization (Liu Xiaohong, 2003). From the perspective of functions, it includes a gradual improvement of clearing tools, investment tools and reserve currency. From the perspective of various elements, including China's current comprehensive national strength, the biggest scale of trade in the world, the relative stability of currency, the developed degree of market system, etc., RMB has had the basic conditions of internationalization, only in the market system (especially the capital market) there are some inadequacies. RMB internationalization has the conditions of free convertibility, and gradually become a tool for international settlement and investment. The strategic goal of RMB internationalization is to make RMB a currency of international trade, investment and reserve. To realize that, it's necessary to push ahead the process of RMB internationalization, further promote the reform of exchange rate system, and open up the capital market of our country. 
Table 1. The Gradual Process of Currency Internationalization

\begin{tabular}{|c|c|c|c|}
\hline Stage & Currency Functions & Range of Currency Functions & $\begin{array}{c}\text { The Degree of Currency } \\
\text { Liberalization and Central Bank's } \\
\text { Responsibility }\end{array}$ \\
\hline Early Stage & $\begin{array}{l}\text { As a invoicing and } \\
\text { settlement currency } \\
\text { in borderer's trade }\end{array}$ & $\begin{array}{l}\text { Currency is used by currency } \\
\text { issuing country and a certain } \\
\text { neighboring country. }\end{array}$ & $\begin{array}{l}\text { Currency exchange and use are } \\
\text { mostly carried out in folk use. } \\
\text { The liberalization degree is low. } \\
\text { Central Bank's main } \\
\text { responsibility focuses on } \\
\text { monitoring the currency } \\
\text { exchange. }\end{array}$ \\
\hline $\begin{array}{l}\text { Elementary } \\
\text { Stage }\end{array}$ & $\begin{array}{l}\text { Extended to frontier } \\
\text { trade. }\end{array}$ & $\begin{array}{l}\text { Currency is used by currency } \\
\text { issuing country and several } \\
\text { neighboring country. }\end{array}$ & $\begin{array}{l}\text { Currency exchange and use } \\
\text { began to take place in official } \\
\text { use. Liberalization degree } \\
\text { increase a little. Central Bank's } \\
\text { responsibility is to expand the } \\
\text { official channel of currency } \\
\text { circulation, and to monitor folk } \\
\text { currency exchange. }\end{array}$ \\
\hline $\begin{array}{l}\text { Intermediate } \\
\text { Stage. }\end{array}$ & $\begin{array}{l}\text { Extended to general } \\
\text { trade. }\end{array}$ & $\begin{array}{l}\text { Currency is used by currency } \\
\text { issuing country, neighboring } \\
\text { country and non-neighboring } \\
\text { countries }\end{array}$ & $\begin{array}{l}\text { The currency becomes a freely } \\
\text { convertible currency. Central } \\
\text { Bank's responsibility is to make } \\
\text { sure that other countries can } \\
\text { change his country's currency. }\end{array}$ \\
\hline $\begin{array}{l}\text { Mid-Higher } \\
\text { Stage }\end{array}$ & $\begin{array}{l}\text { Currency is extended } \\
\text { to be international } \\
\text { investment and } \\
\text { lending tool. }\end{array}$ & $\begin{array}{l}\text { Currency using range expands } \\
\text { to areas including } \\
\text { non-neighbors, with a certain } \\
\text { regional scale. }\end{array}$ & $\begin{array}{l}\text { expands. A sophisticated } \\
\text { domestic financial market is } \\
\text { required. And Central Bank and } \\
\text { other financial regulatory } \\
\text { agencies can supervise it } \\
\text { effectively. }\end{array}$ \\
\hline Senior Stage & $\begin{array}{l}\text { Be extended to be an } \\
\text { international } \\
\text { government reserve } \\
\text { instrument. }\end{array}$ & $\begin{array}{c}\text { Currency is accepted by quite a } \\
\text { few countries. }\end{array}$ & $\begin{array}{l}\text { The currency becomes an } \\
\text { international currency. Central } \\
\text { Bank needs to keep a close eye } \\
\text { on the changes of the supply and } \\
\text { demand situation of currency in } \\
\text { international financial market. }\end{array}$ \\
\hline
\end{tabular}

\subsection{The Influence of Currency Internationalization on National Economic Development}

\subsubsection{Beneficial Effects}

Scholars like Bergsten (1975) (Liu Guanzhou, 2010), Frankel (1991) (Li Chong, 2010), Blinder (1996) (Li Dan \& Cui Riming, 2015) thought the internationalization of a country' currency helps the country increase its welfare by getting seigniorage. Kannan (2009), with the new theoretical model he put forward, carefully studies the improvement the international use of a country's currency can brings to the country's welfare level. The 
improvement of welfare not only came from seigniorage, but also came from the enhancement of currency's purchasing power and the decrease of transaction cost and exchange cost in international trade after the currency internationalization (P Krugman, 1980).

Qiu Kun (2014) thought currency internationalization can avoid exchange-rate risk. Meanwhile, it also eliminates the cost expenditures of hedging and settlement and sales of domestic foreign trade enterprise and improves the management efficiency of enterprise. In addition, the international currency issuing country can directly use its currency for foreign trade and investment, and it is not limited by the exchange rate, which greatly increases the facilitation degree and benefits of trade and investment (P Hartmann, 1998).

Cao Yuanzheng (2013) believed currency internationalization can reduce the cost of external financing and improve international payment capacity. Dollar, for example, has no foreign exchange reserve. If the US has difficulties in external payments, the banknote printing machine just begin to print banknote to solve the difficulties. However, it is another matter whether the banknote is worthless.

\subsubsection{Negative Effects}

Aliber's research (1964) showed that domestic and foreign demand of the currency became uncertain after currency internationalization and that it was ineffective to use interest rates as a tool to control the market. Thus, Central Bank's monetary control ability was weakened (RZ Aliber, 1964). Zhang Yuyan (2010), a domestic scholar, also thought currency internationalization would come with Triffin Dilemma, the responsibility to maintain stability of international finance and some certain negative effects on country economy.

Yin Yahong and He Zerong (2007) thought the financial deregulation and the push of capital market open-up directly brought about financial risks, inflation and deflation as well as brought away them, thus increasing the instability of the financial system in the country. Besides, the transfer of a large amount of currency brought by currency internationalization will make the exchange rate fluctuate greatly, resulting in the risk of financial market turmoil.

Gao Haihong and Yu Yongding (2010) thought RMB internationalization also requires a certain cost, that is, to give up capital account control.

Jiao Jijun (2005) thought the costs of RMB taking a place in international currency are as follows. The effectiveness of monetary policy is weakened or even disappears. The country needs to bear a heavy debt burden. In addition, the demand of currency increases, exchange rate fluctuation is intensified, etc.

In conclusion, RMB internationalization, on one hand, brings seigniorage for economic development, increases the profit of investment and trade and decreases the financing cost. On the other hand, the cost of RMB internationalization brings about some negative effects to economic development such as the decline of currency regulation and control and turbulence of domestic financial market.

\section{Current Development of RMB Internationalization}

Since 1993, China began the process of realizing the currency convertibility under current account and then RMB internationalization began its process. After the Global financial crisis caused by American Subprime Mortgage Crisis, Chinese government and financial authorities were more aware of the financial risks existing in the dollar-centric monetary system and began to realize the urgency of RMB internationalization. Thus, a series of measures were taken to push ahead the process of it. Details of the measures are as follows.

\subsection{Quantitative Analysis of RMB Internationalization}

To measure the level of RMB internationalization, this paper uses the absolute indexes of RMB in trade settlement, investment and reserves to illustrate the level of RMB internationalization, based on the international valuation, payment function and reserve function of international currency. Meanwhile, the paper also uses a relative index, RMB Internationalization Index (RII) compiled by Renmin University of China, to measure the current situation of RMB internationalization

(1) The Use of RMB in Cross-border Trade

The scale of RMB settlement in current account maintains a fairly rapid growth, as shown in the Figure 1 below. RMB settlement in trade in goods showed a development trend of increasing year by year. In 2015, the amount of RMB settlement in current account reached 7.23 trillion yuan, increasing its year-on-year growth by $10.4 \%$. Among that, the amount of RMB settlement trade in goods reached 6.39 trillion yuan, increasing its year-on-year growth by 8.5\%. And the amount of RMB settlement trade in service and other current accounts reached 843.2 billion yuan, increasing its year-on-year growth by $28.4 \%$. 


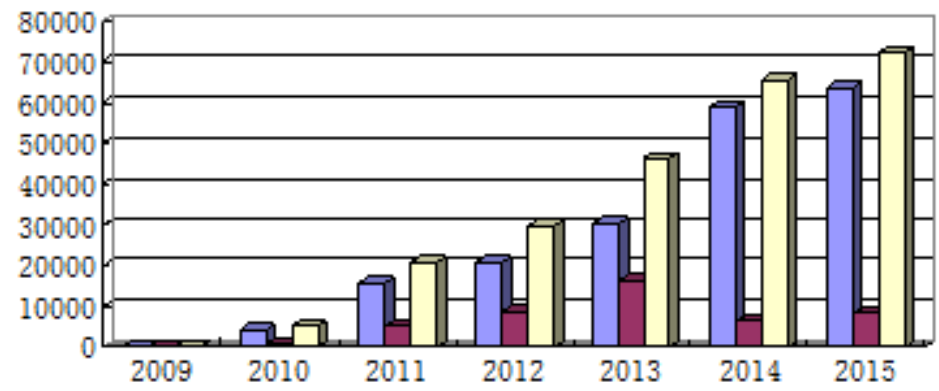

Data Source: People's Bank of China

Figure 1. The Development Trend of RMB Settlement in Trade in Goods and Trade in Service From 2009 to 2015 (Unit: a hundred million RMB)

(2) The Use of RMB in Cross-border Direct Investment

In 2015, the amount of RMB settlement in cross-border direct investment reached 2323.3 billion yuan, increasing its year-on-year growth by $121.6 \%$, among which the amount of RMB settlement in ODI reached 736.2 billion yuan, increasing its year-on-year growth by $294.4 \%$. And the amount of RMB settlement in FDI reached 1587.1 billion yuan, increasing its year-on-year growth by $84.1 \%$.

As shown in Figure 2 below, from 2011 to 2015, no matter judging from the ODI or FDI, the RMB settlement amount of cross-border direct investment showed a rapid growth trend.

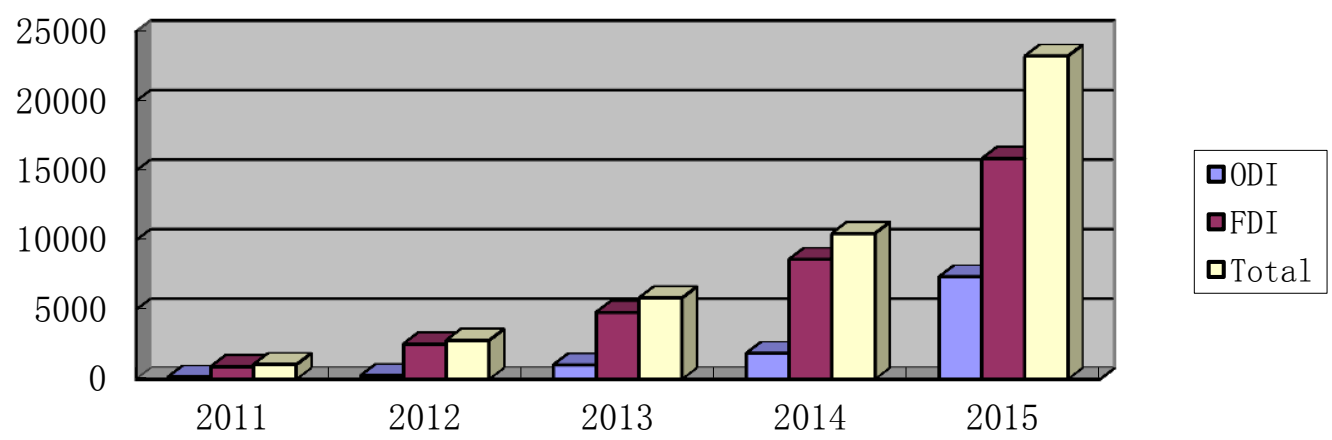

Data Source: People's Bank of China

Figure 2. The Development Trend of ODI and FDI From 2011 to 2015

(Unit: a hundred million RMB)

(3) RMB in International Reserve

In 2014, Chinese bond market totally issued RMB bond 11 trillion yuan, increasing its year-on-year growth by $22.3 \%$. Up to the end of 2014, the balance of bond custody, including the central bank bills custodian, were 35 trillion yuan, increasing its year-on-year growth by $18 \%$. According to incomplete statistics, by the end of April, 2015, a total of 232 foreign institutions were allowed to enter the inter-bank bond market within the territory of China. The balance of bond custodian of was 643.61 billion yuan. The balance of RMB assets that foreign central bank or monetary authorities held in bonds, stocks, deposits, etc. were about 666.7 billion yuan.

(4) RMB Internationalization Index

RMB Internationalization Index (RII) refers to the indicator data that describe the degree of RMB internationalization in an objective, dynamic and scientific way from the perspective of international currency's functions. In RII, trade valuation, financial valuation and official foreign exchange reserves almost share the same proportion, one third. Specific indicators are shown in Table 2 below. 
Table 2. Constituent of Currency Internationalization Index

\begin{tabular}{|c|c|c|}
\hline Primary Index & Secondary Index & Three Index \\
\hline \multirow{4}{*}{$\begin{array}{l}\text { Used for International } \\
\text { Valuation payment }\end{array}$} & Trade & The proportion of RMB settlement in World Trade \\
\hline & \multirow{3}{*}{ Finance } & The proportion of RMB credit in global foreign credit \\
\hline & & $\begin{array}{c}\text { The proportion of RMB bonds and notes in the issuance of } \\
\text { international bonds and notes }\end{array}$ \\
\hline & & $\begin{array}{c}\text { The proportion of RMB bonds and notes in the balance of } \\
\text { international bonds and notes }\end{array}$ \\
\hline & & The proportion of RMB direct investment in global FDI \\
\hline $\begin{array}{l}\text { Used for International } \\
\text { Reserves }\end{array}$ & $\begin{array}{l}\text { Official Foreign } \\
\text { Exchange Reserve }\end{array}$ & $\begin{array}{c}\text { The proportion of RMB reserves in global foreign exchange } \\
\text { reserves }\end{array}$ \\
\hline
\end{tabular}

In RII index system, each index itself is a specific proportion. Thus, RII can be compiled by getting a weighted mean.

Compiling Formula:

$$
\mathrm{RII}_{t}=\frac{\sum_{j=1}^{6} X_{j t} \omega_{j}}{\sum_{j=1}^{6} \omega_{j}} * 100
$$

In this formula, $\mathrm{RII}_{t}$ represents to the RMB internationalization index of phase t. $\mathrm{X}_{j t}$ represents the value of the $\mathrm{j}$ variable in phase t. $\omega_{j}$ represents the weight coefficient of the $\mathrm{j}$ variable.

Economic meaning of RII: if RMB is the only international currency in the world, numerical value of each index in RII index system should be $100 \%$, and the value of RII is 100 . Conversely, if RMB is not used in any international economic transactions, numerical value of each index should be 0 , and RII is 0 . If the value of RII is bigger and bigger, it means RMB functions more in the international economy as an international monetary. For instance, when the value of RII is 10 , it means in trade in asset like international trade, capital flows and official foreign exchange reserve, $10 \%$ of the trading volume are in RMB. Thus, RII can be used to measure the level of RMB internationalization.

In recent years, the indicators RMB of internationalization continue to increase. With policy of cross-border RMB, further improvement of clearing arrangements and continuous expansion of offshore market, the acceptable degrees of RMB in international trade, international financial transactions, currency reserves and other aspects is increasing faster and faster. The level of RMB internationalization is increasing significantly. It can be found in Figure 3, by the end of 2015, the value of RII reached 3.6, increasing by more than ten times in five years. It means that among international trade, capital flows and official foreign exchange reserve, $3.6 \%$ are in RMB.

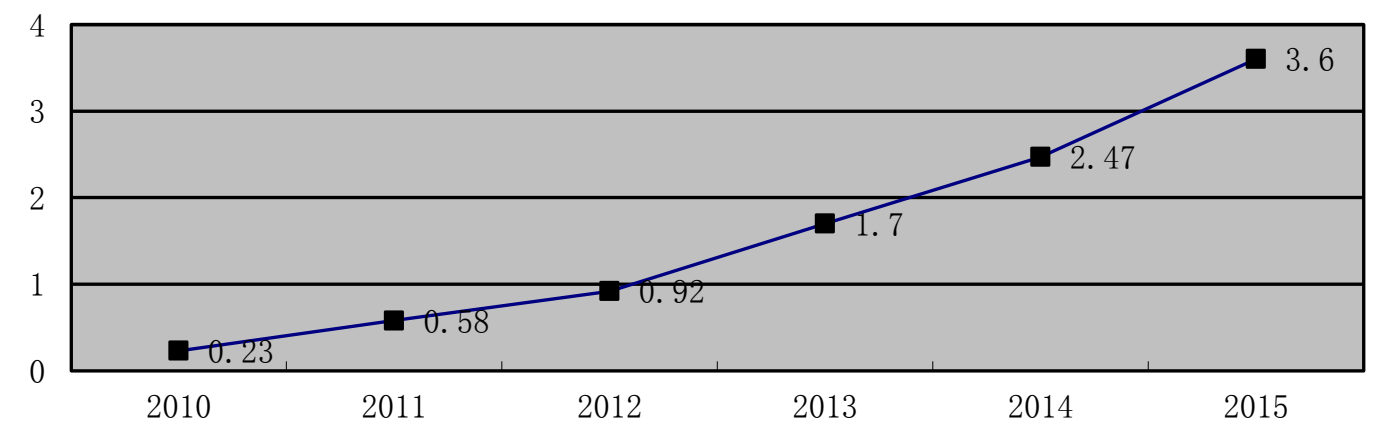

Data Source: Organized from "RMB internationalization report" of the International Monetary Institute, Renmin University of China, 2010-2015

Figure 3. RMB Internationalization Index (2010-2014) 
Comparing RMB Internationalization Index with that of dollar, euro, yen and pound, as shown in Table 3, it can be found that the degree of RMB internationalization has an obvious distance with that of other currencies mentioned above, and there is a lot of room for improvement. Comparing the proportion of different kinds of international currencies in the international monetary system, as shown in Figure 4, we can find the dollar and the euro's internationalization index accounted for almost $88 \%$. It means that in trade in asset like international trade, capital flows and official foreign exchange reserve, $88 \%$ of the trading volume are in the dollar and the euro. RMB accounted for a precious small proportion, only $3 \%$.

Table 3. Internationalization Index of Major World Currencies (2010-2014)

\begin{tabular}{c|ccccc}
\hline Year & 2010 & 2011 & 2012 & 2013 & 2014 \\
\hline Dollar & 53.37 & 52.41 & 52.93 & 52.96 & 55.24 \\
Euro & 25.60 & 26.79 & 26.68 & 30.53 & 25.32 \\
Yen & 4.31 & 4.48 & 4.60 & 4.27 & 3.82 \\
Pound & 4.24 & 4.10 & 4.18 & 4.30 & 4.94 \\
RMB & 0.23 & 0.58 & 0.92 & 1.70 & 2.47 \\
\hline
\end{tabular}

Data Source: Organized from "RMB internationalization report" of the International Monetary Institute, Renmin University of China, 2010-2015
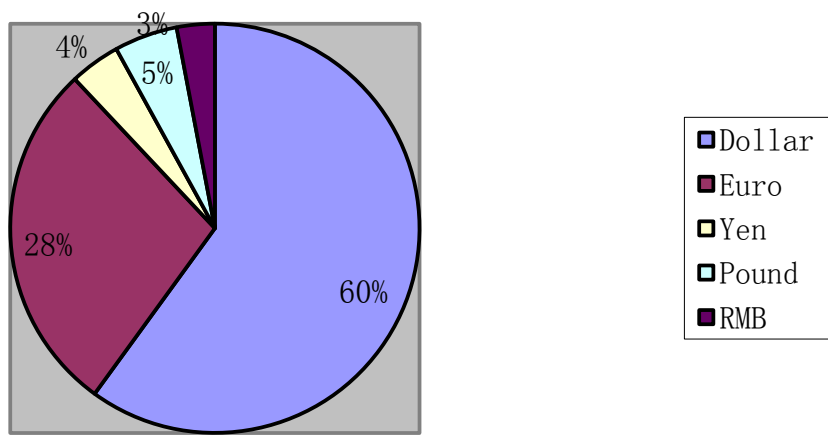

Data Source: Organized from "RMB internationalization report" of the International Monetary Institute, Renmin

University of China, 2010-2015

Figure 4. Proportion of International Index of Different International Currencies in 2014

In conclusion, RMB has successfully joined the SDR basket, becoming the world's fifth largest currency, but according to the characteristics of the gradual process of currency internationalization in Table 1, synthetically considering the use of RMB in cross-border trade and cross-border investment, situation of RMB international reserves and RMB internationalization index, the process of RMB internationalization is still in the initial stage, and the degree of internationalization is far lower than some international currencies such as dollar, euro and yen. Therefore, the process of RMB internationalization still requires further promotion and improvement.

\subsection{Current Measures Taken by Our Country to Promote RMB Internationalization}

(1) Accelerate the financial reform

In 2014, Chinese government accelerated the financial reform and made substantial progress in the openness of monetary market as well as the market-oriented reform of exchange and interest rate. This measure not only helps provide the system safeguard for building efficient and perfect modern financial system, but also offers important support for further development of the RMB internationalization. For example, when three privately-owned banks, Micro-public, civil and commercial Wenzhou and Tianjin Jincheng, were set up in July 2014, it meant that the original financial monopoly was broken. The foundations of these three private banks helped both relieve the small and medium-sized enterprises financial problems and improve the efficiency and fairness of Chinese financial markets. Yet in November 2014, People's Bank of China claimed that the interest rate floating range of financial institutions deposit was expanded to 1.2 times the benchmark interest rate, at the same time, they asked the whole society for public opinion about the Deposit insurance Ordinance (Draft for comment). Obviously, there was a deeper and further development in the marketization of interest rate. 
What's more, in order to conform to the higher level of the basic requirements of reform and opening up, the cross-border RMB policy changes continuously in the simplification of business procedure and approval procedure as well as enlarge the scope of application, which shows the tendency from the pilot area to the national promotion, from the enterprise to the individual opening, from trade accounts to capital and financial accounts. These finally complete the trade and finance two-wheel driven model and accelerate the process of RMB internationalization.

(2) Advance of the RMB exchange rate mechanism reform

Nowadays, RMB exchange rate is basically next to the balanced level. The stability of currency value serves as an effective support for the enterprises going-out. As the reform of RMB exchange rate formation mechanism gains the practical improvement, the market-oriented pricing mechanism is optimized deeply and the market efficiency is improved obviously. We can mainly see it in following fields.

Firstly, market's influence on prices rise obviously and the exchange rate flexibility is increased remarkably. The RMB exchange rate floating range has been extended from $0.3 \%$ to $0.5 \%$ to $1 \%$, even to $2 \%$. In other words, the practical extension of the floating range shows us that we are speeding up the exchange rate reform and the market's influence on price is rising apparently.

Secondly, the People's Bank of China exits basically the normalized market intervention which results to the improvement of market efficiency. Since the second quarter of 2014, the People's Bank of China has quitted the normalized market intervention. It plays a role as the price supervisor instead of a price maker. At the meantime, in order to improve market efficiency and lower the economic agents' exchange cost, the foreign exchange transaction center is authorized by the people's bank of china to conduct direct trading of RMB against pounds, KRW, euro, Singapore dollar, New Zealand dollar and so on among the bank market.

Thirdly, besides deepening the foreign exchange management system reform, we streamline administration and delegate power to the lower levels. At the end of 2014, we eased the inter-bank foreign exchange market access policy, cancelled the qualification permission in advance and allowed more main bodies to participate in the foreign exchange market. What's more, qualified money broking companies are permitted to carry out relevant business in the inter-bank foreign exchange market.

(3) Establish RMB offshore market.

Since the HK monetary authority officially conducted RMB business in HK in 2003, the RMB offshore market has received quick development. Lately in December 2014, the HK RMB deposit was up to1003. 557 billion, which accounted for $40 \%$ of the offshore RMB total deposits. Also, there are some small-scale RMB offshore markets in HK, Taiwan, Singapore and London. Additionally, our country established the renminbi clearing bank successively in London, Paris, Frankfurt, Seoul, Luxembourg, Doha, Toronto, Sydney and so on in 2014.The foundations of several RMB clearing banks plays an important role in the development of the renminbi offshore market. Furtherly, it not only helps improve the recognition degree of the RMB in the world but also encourages the cross-border usage of RMB widely in such fields as international trade clearing and investment, etc.

(4) Sign currency swap agreement

As of January 2015, our country has been signed the currency swap agreements with 23 countries or regions. The swap scale has been up to $¥ 3541.2$ billion. And there are some advantages of the extension of the RMB swap scale: on one hand, it can minimize the exchange risk of relevant currency to maintain the financial market's stability. On the other hand, it can also promote the circulation of RMB in foreign countries. In China, government always carries out the stable currency policy and makes the RMB's currency value calm at home and abroad in these few years. As a result, RMB gains high reputation in the world, which makes it a reality that RMB is recognized by many countries to serve as the payment and settlement currency. In fact, RMB, named "little dollar", has been the hard currency in many countries or regions in Southeast Asia.

\subsection{Exiting Problems in RMB Internationalization}

(1) China's economic strength is still inadequate, although it is the world's second largest economy, the per capita GDP is still relatively low, which is just only the level of developing countries. Strong economic strength is the common feature of the international currency issue, and it's also a necessary condition for a country's currency to become an international currency. Therefore, the economic fundamentals, especially the overall size of the economy, is an important factor affecting the degree of currency internationalization, it can directly affect the central bank's international reserve currency share. Lichong analyzed and summed up the experience of the internationalization of the pound, the dollar in 2013. He thought that the first economic strength of the world is the 
fundamental factor in the realization of the pound internationalization. The dollar also relies on the world's first economic strength and the establishment of the Bretton Woods system that step on the internationalization (Yin Yahong \& He Zerong, 2007). This is great enough to understand that the position of national currency is directly established in the economic basis of the country (Ye Huaguang, 2010).

(2) The opening of capital market is not enough, the proportion of foreigners holding Chinese shares as well as the proportion of foreigner companies come to China to issue stocks is low. In terms of the present situation of China, in the financial market, the number of listed companies, the total amount of asset and asset's securitization do have a great development degree, we can almost catch up with developed countries. But the limitations of domestic financial market are very obvious. For example, the financial market openness is not enough, the proportion of foreigners' holding shares is lower than $1 \%$, the competition isn't full, the efficiency of finance is low, either. Therefore, the RMB internationalization requires that China's financial system need to introduce competition mechanism and develop foreign ownership, foreign companies listed in China. Now QFLL and Shanghai-Hong Kong Stock Connect program are only a matter of expediency, it needs for further liberalization. In addition, the development of RMB offshore market is not perfect, the lack of RMB backflow mechanism is also an important factor to hinder the internationalization of the RMB. As the Chinese government continues to accelerate the pace of internationalization of the RMB, the amount of RMB circulation abroad is increasing, but the development of the offshore market is not perfect, the financial supervision mechanism of China can't reasonably control the offshore RMB, the channels of RMB's return flow is lack, and the opportunity cost of holding RMB is large either (Yung Chul Park \& Chi-Young Song, 2011).

(3) There are too much restraint government impose on the finance, such as foreign exchange control and that RMB cannot be exchanged freely. A currency to become an international currency must have a highly developed and open financial market as its support. Highly open financial market is beneficial to improve the efficiency of market, to lower the cost of transaction. It can also reflect the supply and demand conditions of various financial resources more accurately and timely delivery them to the market participants.

For example, in the process of dollar internationalization, the stable and developed financial system is the power and source of its further expansion and deepening. It mainly includes two aspects. Firstly, the status of the United States in the international financial institutions (GATT, the International Monetary Fund, the World Bank) preserves the status of dollar. Secondly, the enrichment and innovation of financial products, the development of financial markets and the supervision of regulation for the dollar internationalization. Followed by the rich financial products and innovation, the development of financial markets and norms of regulation provide a stable boost for dollar internationalization. The market plays a leading role in the process of dollar internationalization. Financial derivatives are very active and abundant under the free resource allocation of market (Yu Cheng, 2015). The government just pushes from coordination and establishes financial regulators with clear division of labor, formulates reasonable and perfect financial regulation. That enables the financial market to be in a benign environment under the rules so that constructed and stable financial system can push the dollar go from home to world.

\section{Analysis of Opportunities and Risks "The Belt and Road" Brings to RMB Internationalization}

With the construction of "The Belt and Road", the use scope and scale of RMB in international trade and finance field will continue to expand. The construction of Silk Road Economic Belt and Maritime Silk Road provided scarce investment and financing opportunities as well as marketing conditions for RMB internationalization. In the meantime, RMB internationalization also brings some challenges and risks. How to grasp the investment and financing opportunities and marketing opportunities created by the construction of "The Belt and Road", how to prevent and control various risks which may come up, both play essential roles in RMB internationalization. Therefore, the following passage will specifically analyze the opportunities and risks The Belt and Road" brings to RMB Internationalization.

\subsection{The Opportunities "The Belt and Road" Brings to RMB Internationalization}

(1) The deepening of trade cooperation will promote the pricing and settlement of RMB

In recent years, the trade between China with countries along the routes developed rapidly. Over the past five years, the continued growth in the share of trade has won a broad market acceptance for RMB internationalization. Whether it is the ancient Silk Road economy or new Silk Road economy, its development cannot do without the trade and cooperation between countries. Both the size and potential of countries along the routes are very great, making China's trade growth momentum appears large. Statistics of Ministry of Commerce show that in 2015 the bilateral 
trades between China and countries along the routes amounted to 995.5 billion dollars, accounting for $25.1 \%$ of the total. For the first two months of this year, the bilateral trade amounted to 134.1 billion, accounting for $26.26 \%$ of the total. Thus, bilateral trades between China and the countries along the routes have great potential.

(2) Huge investment demand will promote the circulation abroad of RMB

Huge investment demand "The Belt and Road" will bring provide RMB internationalization with advantage conditions. Countries along the routes have great potential to have investment cooperation with China. The demand of investment facilitation is fairly strong. In recent years, Chinese direct investment on the countries along the routes grow rapidly, and regional investment demand bloom. Since 2013, countries along the routes gradually become the focus of China's foreign direct investment. Growth rate per annum of investment is up to $51 \%$, higher than other regions. In 2013, among the top 20 countries and regions receiving Chinese foreign direct investment, countries along the routes occupy 10 of them. Last year, the total amount of that China enterprises directly invest in countries along the routes was 14.82 billion, increasing its year-on-year growth by $18.2 \%$.

(3) Construction of financial platform will ensure the smooth progress of the RMB internationalization

After the issuing of "The Belt and Road", the BRICs Development Bank, the Asian Infrastructure Investment Bank and Silk Road Fund and other financial platform established one after another, in order to provide financial support for countries along the routes, to promote infrastructure construction and to guarantee the RMB internationalization be in process smoothly.

In the financial platform mentioned above, as for the degree of openness, Asian Infrastructure Investment Bank is highest. It involves most western countries and major Asian countries. The second one is the BRICS Development Bank. Although it was founded in order to avoid the financial crisis, but now its most important task is to provide financial assistance for infrastructure construction of the countries along the routes. The lowest one is the Silk Road Fund. Currently it was entirely funded by China, but after operating for a period of time, international investors can also participate in it. In the process of capital output of the three financial institutions, due to China's current international status, there must be a part of the flow of funds which is RMB. Thus, process of RMB internationalization accelerates. In addition, in recent years, the construction of offshore financial centers and establishment of several RMB settlement banks will further enhance regional influence and international influence of $\mathrm{RMB}$ and provide security mechanism for RMB internationalization.

\subsection{The Risks "The Belt and Road" Brings to RMB Internationalization}

When we talking about the potential risk RMB may face with during the process of Belt and Road, Bao Jianyun(2015) analyses before the economic, political, security, environmental, cultural aspects and so on, RMB internationalization still have its uncertain factors, including uncertainty of market competition, political stability and policy changes, ecological changes and environmental damage, security and conflict of interests, external forces intervention, and many other aspects. We will put it into details below in three aspects, economic risk, political risk, financial market volatility risk included.

\section{(1) Economic Risks}

The economics risk which the process of Belt and Road must face mainly related to two areas, and the first one is the operational risk when the companies take part in the construction. Countries only the road, especially those landlocked countries in Central and West Asia, they have low degree of market development and weak market supervision must increase the companies' risk during their development. And the second is default risk, including the company default risk and the government default risk. That means, the risk of investment loss and profit uncertainty caused by breach of contract by the enterprises and governments in the participating countries. Finally, the last thing is the economic downturn in the country may cause the risk of business difficulties.

\section{(2) Political Risks}

Furthermore, the instability and policy changes of those countries along the road may bring political risk to the RMB internationalization. Political risk means in the construction process of Silk Road economic belt, the instability brought by political systems and activities, especially some countries in Central and West Asia, their political systems are diverse, political stability is relatively low, party politics is not standardized, political events and political unrest also occur occasionally... The reasons above must affect the economic cooperation and development among countries.

\section{(3) Financial Market Volatility Risks}

Those countries along the road usually have monetary and financial Instability, which may bring financial market 
volatility risk to the RMB internationalization.

The countries along the Belt and Road, apart from China, India, Russia and Turkey as the larger emerging economies that have relatively high level of economic development, most countries' economic development level is expected to heighten. Currency instability, weak anti-risk ability of financial institutions are prone to monetary credit and financial risks.

Monetary and financial risks are obviously in three areas during the Belt and Road construction, the first one is Exchange rate fluctuation risk. Some economies of small scale and the industrial structure of a single economy in Central, Western and Eastern Asia are affected easily by World Economy and Fluctuation of International Financial Market. Currency exchange rate fluctuations is prone to exchange rate fluctuations risk, too. The second one is credit default risk. Large-scale infrastructure construction requires a lot of capital investment and good credit guarantee, in the formation of good credit guarantee system, the government and enterprises are likely to have credit default phenomenon, that may lead to a series of default risk. The third thing is currency devaluation risk. Small-scale economies are vulnerable to fluctuations in their domestic economic growth and international financial markets, and are more likely to become targets for international liquidity, resulting in a devaluation of their currencies.

\section{The Strategies of Promoting the Process of RMB Internationalization with "The Belt and Road"}

The above analysis shows that Belt and Road brought great opportunities in the trade, investment, financial platform for the RMB internationalization. So, government and enterprises should catch the trade and investment opportunities, remote the use of renminbi for bilateral trade, increase the circulation of foreign currency through international investment and financing, and establish a RMB return mechanism through the construction of financial markets to realize a sustainable international circulation of RMB.

5.1 Deepen Economic and Trade Cooperation, Expand the Pricing and Settlement Ratio of RMB in International Trade

The Strategy of Belt and Road could bring great trade demand. In the case of deepening economic and trade cooperation, expand the settlement ratio of the RMB. What we should do in detail is, further expand market opening, promote the construction and upgrading of regional free trade area, thereby reducing the cost of trade cooperation, reduce trade barriers, improve trade liberalization and facilitation level and expand the scale of trade. What's more important is we should promote the use of RMB for valuation and settlement constantly during expanding the trade scale, and particular emphasis on energy and minerals and other bulk products transactions using the yuan for valuation and settlement. Nowadays, RMB settlement is developing quickly, for example China and Russia have already signed the local currency settlement. Not only the general trade of goods using local currency settlement, the two countries are also promoting commodities, including energy, resources and bulk mechanical and electrical products such as the use of local currency settlement. And the use of RMB settlement of commodities can also avoid the risk of falling US dollar prices. However, the function of RMB denomination has not been fully developed. Therefore, we should give full play to China's market position as a major importer of many commodities, do a good job in top-level design, multi-measures to promote the renminbi denominated commodities, such as speeding up international commodity trading platform Construction, and expand the scope of RMB-denominated commodities, improving the supporting financial services of commodities

\subsection{Strengthen International Investment Cooperation and Set Up RMB Direct Investment Area}

Most of the countries covered by Belt and Road are developing countries and emerging economies, they are in the rise of economic development, having great demand of transportation, electricity and information infrastructure investments. It's predicted that the countries along the Belt and Road in ten years would invent 8 trillion dollars in infrastructure, they would need to spend new investment loans 18.5 trillion US dollars in 2040. If these funds with RMB for financing, loans, it will greatly improve the internationalization of the RMB rate.

With a large number of Chinese enterprises to go out in the "Belt and Road" countries to carry out production and business activities, the establishment of industrial parks, the RMB in the this region will also be recognized. Therefore, the direct investment in the countries along the road will gradually be dominated by the RMB, especially China's investment in infrastructure with technical and management experience. China's labor-intensive industries can use RMB investment, which will greatly promote capital, Technology and other factors of production of international mobility, increasing the RMB in China and "along the way" between the countries of the circulation rate, and promoting the formation of a good cycle of the RMB mechanism. We need to causing the demand for the expansion of the RMB from the objective way, thereby enhancing the RMB loans and financing ratio. 


\subsection{Strengthen Intergovernmental Cooperation}

In the process of promoting the internationalization of the RMB, due to the risk of default risk and political instability and policy change, the key to prevent such risks is to strengthen the cooperation among governments. Firstly, Chinese government can sign bilateral or multilateral trade and investment protection agreement with other countries government, for the reason that reducing trade and investment barriers, increasing participation in the construction of enterprises along the way the protection and reducing the risks arising from government replacement. At present, China has signed a Bilateral Investment Agreement with 56 countries along the route, and the scale of foreign investment has been continuously expanded. In 2015, Chinese enterprises have realized a total investment of US $\$ 127.6$ billion which is an increase of 3.6\%. Secondly, build a free trade zone to avoid double taxation. Thirdly, sign currency swap agreements, use RMB investment and trade settlement including RMB in reserve currency, etc. For example, Thailand, Malaysia, Singapore and Indonesia have signed currency swaps with China, which is totaling in 650 billion yuan. It is understood that about half of the ASEAN Central Bank has the RMB into the foreign exchange reserves and said it will gradually increase the reserves of RMB

\subsection{Set up Regional Capital Market}

The securities, bonds and foreign exchange markets of those countries along the route can make reference to "Shanghai and Hong Kong Link", "Shenzhen-Hong Kong" model, gradually opening up China's capital market, encouraging foreign banks, enterprises and residents in the region to buy A-shares and RMB-denominated bonds, and allowing foreign enterprises in the region to go to the Chinese capital market. And of course, Chinese banks, businesses and residents can also buy foreign stocks and bonds, Chinese companies can also go to foreign markets. Thus, we can form a regional interoperability of the capital market, strengthening management according to international, and guarding against market risk

\subsection{Strengthen the Cooperation of Financial Institutions, Set Up RMB Offshore Market}

In financial cooperation, we can gradually create the ways of RMB loans, financing, settlement business and mutual financial offices to facilitate the financing of all parties and settlement.

Furthermore, we must make efforts to expand and establish other offshore RMB center to consolidate the position of Hong Kong and Singapore offshore RMB center. According to the Singapore Monetary Authority statistics, by the end of June 2015, Singapore RMB deposits totaled 322 billion yuan. In the first half of 2015, Singapore and China cross-border settlement of RMB settlement and payment reached 570 billion yuan, accounting for all of China's overseas market of $10.1 \%$. In terms of trade financing, Singapore's local RMB trade financing balance in September was about 251 billion yuan, of which ICBC Singapore Branch RMB trade financing balance of 57.3 billion yuan, accounting for $23 \%$ of the local market. SWIFT data shows that in March 2016, Britain surpassed Singapore to become the world's second largest offshore clearing center. So, if we want to consolidate these RMB offshore centers, we should also efforts to develop other offshore RMB center for the internationalization of the renminbi to create good conditions

\subsection{Prevent Financial Risks}

Although macroeconomic environment is stable in China, our financial regulatory level and the gap between the developed countries is still relatively large, the financial sector is also still in the early stages of opening up and the financial regulatory system has not yet been sound. So, to perfect the legal system of financial supervision, the state should introduce relevant laws and regulations to regulate the current financial market problems, and ensure that regulatory agencies are also under the control of the law. Furthermore, in order to prevent international financial risks, we should enhance the cooperation with the governments and financial institutions of those countries along the Belt and Road, strengthening the monitoring of risk, trying to establish the information sharing mechanism between our country and them to prevent abnormal flow of funds, combating money laundering and malicious acts such as speculation. Of course, we can also set up a common risk prevention fund, set up the financial and insurance projects, and it is scraped business insurance claims and so on.

\section{Conclusion}

Since the strategy of RMB Internationalization and Belt and Road put forward, the proposition that how to promote the internationalization of the RMB process though the construction of Belt and Road has caught the great attention of scholars home and abroad. Based on a large number of predecessors work, applying the Measurement of RMB Internationalization, analyzing the RMB internationalization of the status quo and the challenges faced, combining with the strategic environment of Belt and Road to find ways to promote the strategy of internationalization of the $\mathrm{RMB}$, this paper eventually get the follow conclusions: 
First, at present, the RMB has joined the SDR currency basket successfully, becoming the world's fifth largest currency. Although the RMB internationalization index has risen rapidly in recent years and the growth rate is up to $85 \%$, compared with the dollar, euro and other international currencies, there is still a big gap. RMB internationalization is still only in the initial stage.

Second, one country's economic strength, financial market openness and stable currency value are all important factors influencing the internationalization of the currency. China should make efforts to improve its economic strength and expand the opening degree of its capital market in order to integrate the Chinese capital market into the international capital market, achieve the goal of the free convertibility of the RMB, and marketization of the interest rate and the exchange rate.

Third, the construction of Belt and Road has brought great opportunities for the RMB internationalization in the trade, investment, market opening, etc. We can catch the opportunities of national economic cooperation to promote the international settlement of the RMB, the international investment of the RMB and the international reserve of RMB. Therefore, we must seize the opportunity of Belt and Road to promote the internationalization of the RMB step by step.

Last, the contributions of this paper are to further enrich the theory of currency internationalization by the practice of RMB internationalization and to discuss strategies for establishing a healthy and stable international monetary system. The deficiency of this research is that the measurement model is relatively simple, and the quantitative analysis is weak. The direction of future research is to, from the perspective of building a stable international monetary system, discuss how to develop a multi-polar international monetary system, in which currencies restrict each other and build a unified and unisonous relationship to jointly promote the development of international economy.

\section{References}

Alan S. Blinder. (1996). The Role of the Dollar as an International Currency. Eastern Economic Journal, 3, 127-136.

Ba Shusong \& Wang Zhifeng. (2015). Belt and Road: Important Strategic Opportunity. People's Tribune.Academic Frontiers, 9, 51-61.

Bao Jianyun. (2015).The Investment Opportunity, Market Condition and Risk Distribution That the Construction of Belt and Road bringing to the RMB International. Tianfu New Idea, 1, 12-116.

Bergsten,C. Fred. (1975). The dilemmas of the dollar: The economics and politics of United States international monetary policy. New York, NY: New York University Press.

BJ Cohen. (1971a). The future of sterling as an international currency. International Affairs, 1, 132-134. http://dx.doi.org/10.2307/2613640

Cao Yuanzheng. (2013). Reform of international monetary system and internationalization of RMB. China Market, 3, 53-54. http://dx.doi.org/10.3969/j.issn.1005-6432.2013.03.010

Chou Kun. (2014). Research on the impact of currency internationalization on domestic economic growth. Shanghai: East China Normal University.

Dong Shoukun, \& Yao Xiaoyi. (1997). On the variation of the one undertaking the foreign exchange risk in the process of RMB free exchange. the theory and practice of finance and economics, 1, 32-36.

Gao Cailin. (2008). USD International and the Reference to China . Shanghai Finance, 5, 61-65.

Gao Haihong \& Yu yongding. (2010). The Meanings and Conditions of RMB International. International Economic Review, 1, 53-54.

GS Tavlas. (1991). On the International Use of Currencies: The Case of the Deutsche Mark. Social Science Electronic Publishing.

He Fan. (2009). The Realistic Choices of RMB International. International Economic Comment, 4, 8-14. http://dx.doi.org/10.3969/j.issn.1003-1812.2009.10.002

Jeffrey A. Frankel. (1991). The cost of capital in Japan: a survey. Federal Reserve Bank of San Francisco, Pacific Basin Working Paper Series.

Jeffrey A. Frankel. (2012). Internationalization of the RMB and Historical Precedents. Journal of Economic Integration, Credit and Banking, 3, 329-365. https://doi.org/10.11130/jei.2012.27.3.329 
Jiao Jijun. (2005). The Effect Analysis of RMB Being Among in The International Currencies. Economic Problems, 1, 53-54. http://dx.doi.org/10.3969/j.issn.1004-972X.2005.01.026

Li Chong. (2013). The Revelation for RMB International from GBP, USD and JPY International. Journal of Guizhou College of Finance and Economics, 1, 8-13. http://dx.doi.org/10.3969/j.issn.1003-6636.2013.01.002

Li Dan \& Cui Riming. (2015). The Belt and Road Strategy and Restructuring Global Economy and Trade Pattern. Economists, 8, 62-70.

Li Xiao, Li Junjiu \& Ding Yibing. (2004). On Asianisation of RMB. World Economy, 2, 21-30.

Liu Guanzhou. (2010). The RMB Offshore Financial Market Construction During the RMB International. Jilin: Jilin University.

Liu Xiaohong. (2003). Analysis of RMB Internationalization. Liaoning Economy, 3, 32-35. http://dx.doi.org/10.3969/j.issn.1003-4617.2003.03.021

P Hartmann. (1998). Currency Competition and Foreign Exchange Markets: The Dollar, the Yen and the Euro. General Information, 4, 545-547.

P Kannan. (2009). On the welfare benefits of an international currency. European Economic Review, 5, 588-606. https://doi.org/10.1016/j.euroecorev.2008.10.003

P Krugman. (1980). Vehicle Currencies and the Structure of International Exchange. Journal of Money, Credit and Banking, 12, 513-525. http://dx.doi.org/10.2307/1991725

RZ Aliber. (1964). The Costs and Benefits of the U.S. Role as a Reserve Currency Country. Quarterly Journal of Economics, 3, 445-453. https://doi.org/10.2307/1879476

Tang Yiru. (2015, February 09). The Invention Risk of Belt ad Road. International Finance News.

The Institute of International Monetary Studies in People's University of China. (2015). The Report About RMB International 2015. Beijing: China Renmin University Press.

Wang yizhi. (2015). The Concern About The Risk of Belt and Road. China Invention, 2, 51-54.

Wu Huiping. (2010). A research summary of international currency and currency internationalization. Modern Finance and Economics: Journal of Tianjin University of Finance and Economics, 7, 39.

Wu Xiaoqiu. (2015). China's Capital Market in a Great Country's Finance. Finance Forum, 5, 33-34.

Yang Huai. (1999). The contradiction between expansionary economic policy and non-devaluation of RMB. china foreign exchange administration, 3, 32-33.

Ye Huaguang. (2010). Research on the structural effects of external trade on RMB internationalization. Gansu Finance, 4, 43-46.

Yin Yahong \& He Zerong. (2007). Exchange rate decision model based on currency substitution and empirical analysis. Studies of International Finance, 4, 45-50.

Yu Cheng. (2015). The discovery of RMB International's Road must be fellow. People's Forum, 29, 65-67. http://dx.doi.org/10.3969/j.issn.1004-3381.2015.29.019

Yue Yiding \& Zhang Qi. (2004). Empirical Study of Elasticity of Currency Substitution in China Under Open Conditions. The Theory and Practice of Finance and Economics, 4, 32-37. http://dx.doi.org/10.3969/j.issn.1003-7217.2004.04.007

Yung Chul Park \& Chi-Young Song. (2011). Renminbi Internationalization: Prospects and Implications for Economic Integration in East Asia. Asian Economic Papers, 3, 62-72. https://doi.org/10.1162/asep_a_00100

Zhang Yuan. (2012). The Historical experiences of USD International and the Revelation to China. Review of Economic Research, 37, 85-91. http://dx.doi.org/10.3969/j.issn.2095-3151.2012.37.004

Zhang Yuyan. (2010). RMB Internationalization: agree or disagree?. International Economic Review, 1, 40-45.

Zhou Lin \& Wen Xiaozheng. (2001). Currency Internationalization. Shanghai: Shanghai University of Finance and Economics Press. 